\title{
5 The Geidōmono Genre and Intermedial Acting in Ozu and Mizoguchi
}

\begin{abstract}
Chapter 5 revisits the work of two cinematic giants, Kenji Mizoguchi and Yasujirō Ozu, and their recourse to theatre in The Story of the Last Chrysanthemums (Zangiku monogatari, 1939) and Floating Weeds (Ukigusa, 1959) respectively. In them, the mediums of theatre and film are scrutinised through the self-reflexive genre of geidomono, encompassing films in which the protagonist is a practitioner of one of the traditional Japanese arts. Here, theatre serves both the Mizoguchi and the Ozu films to break down the system at the base of the mediums of theatre and film into their constitutive parts, provide evidence of their reality, and propose a fairer arrangement of them, in particular as regards the ruthless hierarchy embedded in both mediums.
\end{abstract}

Keywords: Kenji Mizoguchi; Yasujirō Ozu; The Story of the Last Chrysanthemums; Floating Weeds; geidōmono; Intermediality

This chapter focuses on the use of theatre in film as a passage to physical reality. In the cases analysed here, drawn from the work of two cinematic giants, Kenji Mizoguchi and Yasujirō Ozu, this reality will be of the artistic mediums themselves, or 'the reality of art' as Visconti (1978: 84) once put it (see Chapter 8). I am referring to Mizoguchi's The Story of the Last Chrysanthemums (Zangiku monogatari, 1939) ${ }^{1}$ and Ozu's Floating Weeds (Ukigusa, 1959), a remake of his earlier A Story of Floating Weeds (Ukigusa monogatari, 1934). In both, the mediums of theatre and film are scrutinised through

1 The Story of the Last Chrysanthemums is the generally adopted translation of this film's title, although alternative translations also exist. The most accurate would be to say, 'The Story of a Late Chrysanthemum', with reference to the protagonist, an actor whose talent takes a long time to bloom. However, for convenience, I will be using The Story of the Last Chrysanthemums in this book.

Nagib, L., Realist Cinema as World Cinema: Non-cinema, Intermedial Passages, Total Cinema. Amsterdam: Amsterdam University Press, 2020 DOI 10.5117/9789462987517_CHO5 
the self-reflexive genre of geidōmono, encompassing films in which the protagonist, usually male, is a practitioner of one of the traditional Japanese arts, such as kabuki, puppet theatre (bunraku) or traditional dance (Satō 2008: 77).

Geidomono, in Japan, was often resorted to in the 1930 s as an alternative to governmental demands for propaganda films as the war efforts escalated. Though the results could be formulaic and contrived, this is not the case of The Story of the Last Chrysanthemums, a dazzling display of narrative and technical command universally recognised as one of Mizoguchi's greatest masterpieces. A paradigm-setting work and turning point within the filmmaker's career itself, the film continues to fascinate critics, filmmakers and audiences alike to this day for its originality and innovations. Floating Weeds, in turn, constitutes a notable departure from Ozu's usual audiovisual tropes and storytelling motifs. Made at a time when there was no external pressure on the director to resort to this already outdated genre, the film evidences Ozu's interest in, and deliberate choice of, geidōmono when for once he had the chance to work with the production company Daiei and to stray away from his, and his long-standing employer Shōchiku's, consecrated style. My argument here will be that the geidomono genre offered both filmmakers the ideal tools with which to conduct, with enhanced realism, a self-reflexive and self-critical assessment of the inner workings of both the theatre and the film mediums, including its ruthless hierarchical system, gender inequality and punitive cast structure.

Mine is certainly not the first attempt at assessing these films and filmmakers through the realist lens. In fact, the application of notions of realism has been tested with regard to Japanese cinema since the 1950s, when European critics first became acquainted with them via the works of Mizoguchi and Kurosawa. Emerging in the wake of Italian Neorealism, which revolutionised cinema after the Second World War, their films were immediately compared by European critics to neorealist milestones and read against the backdrop of nineteenth-century European realist literature and patterns of narrative realism as found in the so-called 'classical' Hollywood cinema. Within the Japanese and Anglophone context, social realism took the upper hand in criticism of both directors, in particular as regards their prewar output. The next section will be devoted to historicising these realist readings, which my intermedial approach aims at once to clarify and complement. I shall then move onto film analysis, starting with a consideration of the ways in which both the Mizoguchi and the Ozu films focus on acting as a means to self-comment on their stellar cast, but also to deconstruct the rigid hierarchy informing kabuki and related theatrical forms, which was 
akin to the authoritarian system then prevailing within the film studios from which these films emerged. The analysis will continue with the examination of the subversive gender politics at work in these films which unveils to the spectator the gruelling training practices at the base of the Japanese star system, both in theatre and film. It will culminate with an assessment of the reversal of the scopic regime (Metz 1982: 61ff) that takes place in both films, through which actors become the privileged spectators of life as it happens, thereby revealing their all-too human condition behind their masks and changing theatre into a passage to reality.

\section{Japanese Cinema and Realism}

Realism in Mizoguchi has been on the agenda since Europe, and the French in particular, discovered him and Kurosawa in the early 1950s. In fact Kurosawa and Mizoguchi functioned as Japanese cinema's port of entry into Europe, thanks in the first place to the Venice Film Festival, which awarded the Golden Lion to Kurosawa's Rashōmon, in 1951, the International Director's Prize to Mizoguchi for The Life of Oharu (Saikaku ichidai onna), in 1952, and the Silver Bear to Mizoguchi's Ugetsu (Ugetsu monogatari), in 1953. Writing in 1955, André Bazin (2018: 166o) hailed the discovery of Japanese cinema as a landmark in film history in the following terms: 'The revelation of Japanese cinema is certainly the most considerable cinematic event since Italian neorealism', going on in another article (Bazin 2018:1667) to compare the Japanese films he had seen to foundational neorealist works such as Roberto Rossellini's Rome, Open City (Roma, città aperta, 1945) and Paisan (Paisà, 1946). Mizoguchi was the most lauded by the French among the newly-discovered Japanese directors thanks, precisely, to what was deemed to be his 'realism'. This distinguished him, in their eyes, from Akira Kurosawa, who was presented by Bazin in mild terms and the rest of the Cahiers du Cinéma writers in the strongest terms as Mizoguchi's unworthy rival. Kurosawa, in turn, was embraced as the best of all Japanese directors by the competing film magazine Positif, generating a famously acrimonious debate between France's two most important film publications. The result, in the Cahiers, was a flurry of heated essays in defence of Mizoguchi by the likes of Jean-Luc Godard, Jacques Rivette, Luc Moullet and Alexandre Astruc. As Godard (1986: 70-71) put it in 1958:

There can be no doubt that any comparison between Mizoguchi and Kurosawa turns irrefutably to the advantage of the former [...] [Mizoguchi's] 
art is to abstain from any solicitation irrelevant to its object, to leave things to present themselves without intervention from the mind except to efface its traces, thus increasing a thousand fold the efficacity of the objects it presents for our admiration. It is, therefore, a realist art, and the mise en scène will be realist.

These sovereign objects Godard identifies in Mizoguchi's films in a way prefigure the autonomous or 'weird' objects that someone like Graham Harman (2005: 74) would describe in the twenty-first century, drawing on speculative realism and its non-correlationist stance (see Chapter 2). Like Godard, Bazin also conceived of realism as the prevalence of the objective over the subjective world, but he went further by recognising in Mizoguchi, and in Japanese cinema as a whole, a seamless interaction between the film medium and the other arts, a cinematic feature he ardently defends in his famous article 'For an Impure Cinema: In Defence of Adaptation' (2009:107). In the Japanese films he saw, this interaction denoted, for him, a 'marvellous infallibility of taste': 'What I most admire in Japanese cinema is that it fuses, without gaps or concession, with the arts of traditional culture, such as literature, theatre and painting' (Bazin 2018: 1668).

At the same time, however, Mizoguchi's realism is praised by Bazin (1985: 261) for its 'authenticity' and, even more paradoxically, its 'purity', in contrast to Kurosawa's embracing of western influences:

[Kurosawa] is evidently very much influenced by Western cinema of the thirties, and perhaps even more by American films than by neo-realism. His admiration for John Ford, Fritz Lang and Chaplin in particular is clear enough. [...] But in [Rashōmon's] wake came many other films - notably Mizoguchi's - which have revealed to us a production which, if not more authentic, is at any rate more characteristic and more pure.

Adopting a similar view, Jacques Rivette (1986: 264) defines 'authenticity' in Mizoguchi's films as the 'universal language' of mise en scène brought 'to a degree of purity that our Western cinema has known only rarely'. The concern with 'purity' is in fact almost an obsession among French film critics and thinkers at the time, one which is revived decades later by Gilles Deleuze (1997: 13), this time a propos of Ozu, who he deems to have invented 'pure optical and sound situations', or 'opsigns' and 'sonsigns', and I will return to this. Connected to the same Cahiers clique, Jean Douchet (1997: 4-5) is another critic who found 'a passionate preoccupation with realism' in Mizoguchi, which he however attributes to his European realist 
literary sources, such as Balzac, Dickens and Dostoevsky, rather than to his Japanese background.

Interestingly, none of the French critics, not even Bazin himself, at the time, ascribed Mizoguchi's realism to his prolific use of the long take and the long shot, the combination of which was famously hailed by Bazin as the realist procedure par excellence. Nonetheless, Mizoguchi may have been the conscious inventor of this cinematic technique, which he drew from the theatrical live action and practised from his 1930 Mistress of a Foreigner (Tojin okiji) onwards. Dubbed 'one-scene-one-cut' cinematography, it became a systematic procedure in his films precisely with The Story of the Last Chrysanthemums, according to his faithful scriptwriter Yoshikata Yoda (1997: 63), and I will return to the ways in which this procedure elicits, in this film, a kind of very Bazinian realism, whilst offering cinema a passage to the reality of theatre as much as that of the film medium.

Elsewhere, the Mizoguchi-Kurosawa rivalry was dismissed, for example, by Audi Bock (1990: 35), a Kurosawa specialist and his official translator into English, who highlights the generational gap between the two and the influence of the former on the latter, not least as concerns realism:

The most obvious influence Kurosawa has felt is Mizoguchi's unflinching realism in the application of the past to the present, the portrayal of personal drama in a broad and fully detailed historical milieu.

As well as in Mizoguchi's meticulous historical reconstitutions, Bock identifies realism in his left-leaning political persuasions and feminist tendencies. 'In the mid-1930s', writes Bock (1990: 40-41), 'Mizoguchi reached a peak of what has been dubbed social realism through his deepening portrayals of women on the screen'.

Striking a similar note, Japanese film critic and historian Tadao Satō (2008: 33ff) sees Mizoguchi's realism or naturalism, as he also calls it, as essentially self-referential and associated with the literary current of the shishōsetsu, or the Meiji-period autobiographical 'I-novel' in Japan. For Satō, Mizoguchi's portrayals of sacrificial women are direct transpositions of the director's personal life experiences, citing as an accomplished example, yet again, The Story of the Last Chrysanthemums, whose sacrificial female protagonist, Otoku, he compares with Mizoguchi's own doting sister, Suzu, who supported him during a long period of his adult life. Satō (2008: 41ff) is in fact the main source for non-Japanese readers when it comes to Mizoguchi's left-wing forays at the base of his prewar social-realist tendencies. Indeed, these can also be detected in The Story of the Last Chrysanthemums in 
the detailed portrayal of poverty-stricken travelling actors, sleeping in communal hostels amongst drunkards and even animals, such as the real acting monkeys carried along by one of the boarders.

As for Ozu, Donald Richie (1977: 5-6), an early expert on the director, attributes his prewar acclaim to the social realism he pioneered in Japanese cinema with I Was Born, But... (Umarete wa mita keredo, 1933). But he also contests critics, such as Imai Iwasaki, who lament the loss of this quality in the director's postwar output, which focuses on well-off rather than workingclass characters. For Richie, Ozu's realism goes beyond the mere belief that 'unhappiness is caused solely by social wrongs': 'it is precisely "day-to-day existence" that Ozu so realistically and hence so movingly captured' (Richie 1977:6). This everyday-life realism is nonetheless achieved with the help of anti-realist procedures which Richie (152ff) equally notes, a case in point being Ozu's disregard for eye-line match, narrative transitions and other rules consecrated by American classical cinema as essential ingredients for the production of an impression of reality. As David Bordwell (2004: 90) explains:

The classical Hollywood cinema canonized the rule of the '180-degree line' or 'axis of action'. This assumed that characters could be arranged so as to face one another and that various shots of their interactions could be taken from camera positions on one side of that axis. [...] It is easy to see that Ozu typically does not obey these precepts.

Bordwell goes on to cite examples of this break in Ozu's oeuvre from as far back as 1934 and A Story of Floating Weeds, remade decades later into Floating Weeds.

$\mathrm{Ozu}$, in fact, could be considered in all antipodal to Mizoguchi. The rigid system crystallised over the years in his films comprised: a very low and static camera eliciting the so-called 'tatami-shots'; a $50 \mathrm{~mm}$ lens that flattens characters in medium close-ups; the 'one line, one shot' procedure, through which shooting is interrupted after each dialogue line; and 'pillow shots' (Burch 1979) or 'curtain shots' (Satō 1987), focusing on objects and landscapes that produce ellipses of time between action scenes. All these techniques stand in stark contrast with the extremely mobile camera, wide-angle lenses, depth of field and the 'one scene, one shot' procedure adopted by Mizoguchi in his films. Nonetheless, the focus on common people, typical of the shomingeki genre, in Ozu's prewar films results in the social realism pointed out by Richie and later by Burch (1979: 154ff), Takinami (2018: 134ff) and others, making them comparable, in this respect, to Mizoguchi's prewar left-leaning films. 
Bazin and the young Cahiers critics were still unaware of Ozu in the 1950s, as until the end of the decade his films were deemed by Shōchiku to be 'too Japanese' for distribution abroad or even for screening at international film festivals. This obstacle was eventually lifted thanks to the efforts of Donald Richie, who in his stint as film curator at the Museum of Modern Art in New York in the 1960s organised an Ozu retrospective there that initiated his dissemination abroad. International acclaim immediately followed and Ozu was enshrined, alongside Mizoguchi and Kurosawa, in the Japanese cinema pantheon outside Japan. From then on the debate on the possible realism of his films gained track, for example, in Burch's book on Japanese cinema (1979: 222), in which his 'pillow-shots' are compared to Mizoguchi's non-anthropocentric principle already noticed by Godard:

[Mizoguchi's] characters tend to desert the frame, or the camera to desert the characters in accordance with a de-centering principle which will assume other, less obtrusive forms in his mature work to come. It is, however, already a fully developed element of Mizoguchi's systemics, corresponding to Ozu's pillow-shots and the tradition of 'uninhabited' shots associated with the Japanese cinema throughout the 1930 .

This prefigures Deleuze's (1997:16) magisterial reading of Ozu's transitional shots of objects and landscapes, which for him 'take on an autonomy which they do not immediately possess even in neo-realism'. In fact, Deleuze (15-16) does the work Bazin and the young Cahiers critics might have done of differentiating Ozu from Mizoguchi and Kurosawa for his 'modern' realism:

In Ozu, there is no universal line which connects moments of decision, and links the dead to the living, as in Mizoguchi; nor is there any breathing space or encompasser to contain a profound question, as in Kurosawa. Ozu's spaces are raised to the state of any-space-whatevers, whether by disconnection, or vacuity.

This generates, for Deleuze, 'instances of pure contemplation', which bring about a symbiosis, 'the identity of the mental and the physical, the real and the imaginary, the subject and the object, the world and the I' (1997: 17). The same applies to Ozu's pillow shots, in which, for Deleuze (17), 'there is becoming, change, passage [...] the bicycle, the vase and the still lifes are pure and direct images of time'. Echoes of Bazin's (2005: 76) definition of realist cinema as 'a cinema of time', drawing on Bergson's notion of durée, or 
duration, can be heard here, as he resorts to in his famous analysis of Vittorio de Sica's meditative neorealist film Umberto D (1952) (Bazin 2005: 79-82).

Time has passed since these critics first attempted to grapple with a cinema whose history and context were hitherto unknown to them, so we can now comfortably leave aside evolutionist, auteurist and biographical aspects of those approaches and make a better-informed assessment of these films that takes into account their cultural context and background. 'Purity', which was combatted by Bazin himself in his defence of 'impure cinema', a precursor of the intermedial method adopted here, is another unhelpful and essentialising concept that imprisons filmmakers in a hypothetical cultural authenticity they themselves wanted to overturn. And there will be no attempt, here or elsewhere in this book, to rank filmmakers according to their 'genius'. My analysis in this chapter will nonetheless draw on all the valuable insights summarised above insofar as they favour the tracing of realism as mode of production in the films in question. I will argue that the geidōmono generic demand opens up in them a passage to the reality of film, theatre and the actors behind the characters, a constitutive element of these films that has been hitherto entirely neglected.

In short, this chapter is interested in the self-reflexive realism, not of the auteur, but of the films, resulting from an inward look at the materials available for theatre and film making within the geidomono genre, which my analysis below will attempt to flesh out.

\section{The Reality of Acting for Film and Theatre}

Theatre being the very subject of the geidomono genre, it allows for a selfreflexive discussion of an actor's stage skills whilst enabling a fascinating parallel with the cast's screen talent. Indeed, rather than succumbing to the prestige of their celebrated stars, The Story of the Last Chrysanthemums and Floating Weeds present for spectatorial awareness and intellectual participation the inner workings of performance through a constant focus on the backstage that unveils the tyranny inherent in kabuki training, as well as the clashes in acting for film and theatre, both of which deny the actors an easy path to glory. In so doing, they subtly subvert the system at the basis of their own stellar cast, whilst exposing their plight within the rigid hierarchy of the Japanese studio system.

As is well known, both Mizoguchi and Ozu subjected their actors to a relentless questioning and deconstruction of their star persona and celebrity status. Both directors worked with the most prestigious actors 
of their time. Setsuko Hara, the so-called 'eternal virgin of Japan', and Chishū Ryū, playing the role of the middle-age father since his early 205 , are a constitutive part of Ozu's films. So closely entwined to the Japanese star system is Ozu's work, that it resulted for example in Setsuko Hara's character Noriko lending her name to a celebrated trilogy by the director, the 'Noriko Trilogy', composed of Late Spring (1949), Early Summer (1951) and Tōkyō Story (1953). The name Noriko itself became one of the most popular female names of the early postwar generation (Phillips 2003: 159). The same applies to Kinuyo Tanaka in relation to Mizoguchi's films, her regular casting by the director only thinly veiling a much rumoured (and to all effects platonic) love affair between the two. But this did not secure an easy ride for these celebrated stars, within a rigidly hierarchical studio system on top of which reigned the almighty film director. A quick anecdote illustrates this state of affairs. Tanaka recalls that she had been dieting during the shoot of Sanshō the Bailiff (Sanshō Dayū, 1954) in order to look haggard in her role. But she decided to have a steak the night before recording her last and minor scene in the film. The next day on the set, Mizoguchi somehow detected the 'clandestine steak' in her voice and exposed her to five hours in the freezing winter weather and numerous exhausting runs of her scene before her voice was 'tuned back' to a level of harshness that chimed with her character (Le Fanu 2005: 42).

Tales along the same lines also abound with relation to Ozu. In Floating Weeds, a film exceptionally made with Daiei rather than his home-studio Shōchiku, as noted above, Ozu cast Daiei's top female actor, Machiko Kyō, who had to her credit masterpieces such as Rashōmon (Akira Kurosawa, 1950) and Ugetsu (Kenji Mizuguchi, 1953), and paired her off with the formidable stage and screen veteran Ganjurō Nakamura. The actors' impressive CV, however, did not stop Ozu from subjecting them to relentless repetitions, in one occasion sending both home with a temperature, after making them perform a row in the rain for a whole day (Richie 1974: 144).

Richie (1974:146) compares Ozu's method with Robert Bresson's, suggesting that 'both men had a horror of acting as such'. In order to obtain a mechanical delivery completely detached from their star personas, Ozu kept his actors in the dark about his real intentions and obstinately undermined their self-confidence through repeated runs of the same gestures and lines. This is why the extraordinary Chishū Ryū was convinced of his lack of talent, as seen in this statement:

Since my clumsiness was well known at the studio, all the staff used to switch off the lights and go off someplace when my turn came. Ozu and I 
were left alone on the set and he would let me rehearse endlessly [...] until somehow I at last managed to do what he wanted. (Richie 1997: 146-147)

And yet, so key to the Ozu style was Ryū, that even when there was no role for him in a film, he would make a kind of cameo appearance, as in Floating Weeds, where he plays for a few minutes an elusive landlord.

My argument here will be that, unfair and inexcusable though it may be, such a method was also the way both directors found to cause a crack in the system through which to criticise this very system. In particular, from The Story of the Last Chrysanthemums onwards, Mizoguchi established a novel way of shooting for cinema, drawing heavily on theatre, that affected not only the length of the shot but also the style of acting. Ozu's work at Daiei, in turn, gave him freedom to push to the extreme his pursuit of a new acting style that cast a critical eye on the very act of performing. Let us see how this procedure worked in the films in focus here.

As already pointed out, The Story of the Last Chrysanthemums is a geidōmono tale chosen by Mizoguchi to eschew the pressure he was under to make propaganda films in an increasingly militarised Japan. It is the first and only remaining film out of four he directed pertaining to this genre. It was followed by A Woman of Ōsaka (Naniwa onna, 1940), The Life of an Actor (Geidō ichidai otoko, 1941) and Three Generations of Danjurō (Danjurō sandai, 1944), all of which are unfortunately lost. Particularly regrettable is the loss of $A$ Woman of Ōsaka, a film scriptwriter Yoda (1997: 28) deems a masterpiece and which, like The Story of the Last Chrysanthemums, won the Ministry of Culture prize of that year. A Woman of Ōsaka also marks the beginning of the collaboration between Mizoguchi and the famous actress and later film director Kinuyo Tanaka, who according to Yoda (28) delivers a brilliant performance in it. As critics have reiterated (Andrew 2016; Kirihara 1992: 137ff), geidōmono was not an unwelcome imposition on Mizoguchi, who relished the opportunity to offer faithful, and for some critics 'realistic', reconstitutions of past events. Indeed, the film is based on the real story of celebrated kabuki actor Onoe Kikunosuke II, the stepson of one of kabuki's most famous actors of his time, Onoe Kikugorō V. His life was the subject of a 1932 novel, The Story of the Last Chrysanthemums, which is at the basis of Mizoguchi's screen adaptation.

In the film, acting provides the axis around which the story revolves. Kikunosuke (played by celebrity shinpa actor Shōtarō Hanayagi) is portrayed as someone living in the shade of his stepfather's power and oblivious of his own acting shortcomings, surrounded as he is by hypocritical colleagues, relatives and geishas. One day, he is unexpectedly confronted by 
Otoku (Kakuko Mori), the wet nurse of Kikugorō's legitimate baby son, who candidly reveals to him the damning opinion on his acting held by everyone, including her, and encourages him to work harder. Kikunosuke immediately falls for her, but their romance is fiercely opposed by his step parents. He then elopes with Otoku and starts a life of misery, while continuing to train as an actor in Ōsaka and then with a travelling theatre troupe. Rediscovered by a relative years later, thanks to the intervention of a now consumptive Otoku, Kikunosuke returns to the kabuki stage, triumphing successively in Nagoya, Tōkyō and Ōsaka, while Otoku languishes in poverty and finally dies.

This story connects with reality on many levels. It is in the first place based on the lives of real actors, but it is also a by-product of an extremely popular adaptation of the novel to the shinpa stage. Shinpa (literally, 'new school') theatre is a variation of kabuki, focusing on more contemporary and realistic stories as opposed to kabuki's kyūha (or 'old school'), devoted to historical and heroic dramas. Mizoguchi was a shinpa devotee and drew on its style and stars for the conception of The Story of the Last Chrysanthemums. Despite being much older than his character in the film, Shōtarō Hanayagi was cast for the main role of Kikunosuke thanks to his talent and renown as a shinpa actor.

In his endeavour of fidelity to the film's theatrical roots, and in line with his penchant for historical realism pointed out by Bock, Mizoguchi even contemplated the possibility of inviting the legendary kabuki actor Kikugorō VI - the legitimate son of Kikugorō V who is still a baby in the film - to join the cast. In an interview, Mizoguchi relates an interesting meeting with Kikugorō VI:

As regards theatre, I planned to make a film with Rokudaime Kikugorō Onoe [or Kikugorō Onoe VI]; I went to kabuki to watch Meikō Kakiemon [The Famous Artisan Kakiemon, by Enomoto Torahiko] and went to meet him on the backstage. He told me: 'Today I'll play in a cinematic way, pay close attention'. Seen from the stalls, his recitation seemed really different from his usual style, it was so to say a realistic way of performing, with very natural and essential movements. At the end, he asked me in the backstage: 'How did you like it?', I replied: 'You displayed a cinematic performance, and it was very accomplished, but the other actors around you continued to play in the classical way, so there was a mixture on stage. When you play in my film the other actors will have to mature'. 'You are right, quite right...', said Rokudaime, but he died before making the film, it's a real shame! (Kishi 1980: 143). 
Mizoguchi's memory might have betrayed him in this account, as Rokudaime only died in 1949, ten years after the completion of The Story of the Last Chrysanthemums. Whatever the case, this reminiscence indicates the extent to which he researched into an actor's artistry and its various degrees of naturalness and realism in order to shape up his characters. This can be observed from the astonishing opening of the film, when the protagonist Kikunosuke is introduced to us. It shows a moment of 'bad acting' by Hanayagi impersonating the young Kikunosuke who confronts his father, Kikugorō V, in the role of a samurai, in an elaborate choreography. Let us look at this scene more closely.

Satō reminds us that when Mizoguchi started in the silent film era, using shinpa actors in the Nikatsu Mukojima Film Studio, female roles were still played by onnagata, or female impersonators. Hence close-up shots were avoided because they could reveal their male features, such as their Adam's apple (Satō 2008: 21). The same principle was applied to Hanayagi in The Story of the Last Chrysanthemums, who was much older than his character hence unsuitable for close-ups (Kirihara 1992: 139). In this opening scene, however, Hanayagi deserves some of the rare medium close-ups of the film, as if to illustrate Mizoguchi's point about the real Kikugorō's acting for film within a theatre play, cited above, that is to say: Hanayagi's acting seems perfectly accomplished for film, as the close-ups demonstrate, but will be subsequently criticised, first by his irate stepfather then by everybody else, including a woman in love with him, as inadequate for kabuki. Consequently, the film spectators are placed in the disconcerting situation of having to convince themselves that an actor's brilliant performance is in fact bad. Ambiguity of expression, considered by Bazin (1967: 31ff) the quintessence of realist cinema, and consequently spectatorial participation, the main requirement for medium realism, are thus enabled, changing the film spectator into the unexpected judge of an actor's performance for two different mediums.

The play in question is Ghost Story of Yotsuya (Yotsuya kaidan, by Tsuruya Nanboku VI), a piece full of special effects, including the trick called toitagaeshi, through which actors insert their faces into holes on dummies, in this case, the ghosts of the murdered lovers Oiwa and Kohei (Kirihara 1992: 151). The ghosts are uncovered by the celebrated actor Kikugorō V, in the role of a samurai, who then confronts his stepson, Kikunosuke, onstage, in a choreographed fight. However, as Davis (1996:114) notes, this crucial moment in the scene 'is elided when the camera pans to show Kiku's entrance':

The trickery really consists in the interplay of theatrical presentation and cinematic representation: filmic techniques are used to distract us 
from the central performance (by Kikugorō) to the mediocre posturings of a peripheral character $(\mathrm{Kiku})$.

In other words, continues Davis (116), 'Kikugorō has been upstaged, so to speak, by what he excoriates as a miserably incompetent performance'. The fact, however, remains that what the film fiction shows as 'mediocre posturings' is in reality excellent acting for film by Hanayagi. This is how, in The Story of the Last Chrysanthemums, a fictional story changes into the diverging realities of acting for film and theatre, and of the rivalry between the actors working for these different mediums.

\section{Gender Politics and the Subversion of the Star System}

Ozu's Floating Weeds, with its comedic and derogatory quips directed towards Japan's theatrical traditions stands, on a first approach, in stark contrast with The Story of the Last Chrysanthemums, in which the focus on acting and performing combines with a highly melodramatic tale of injustice towards the lower classes and the female gender. In terms of genre and subject matter, however, the Mizoguchi film is very close to Ozu's, given that both adhere to the geidōmono genre by means of a critical view of the ruthless hierarchical system that makes the very backbone of kabuki and related theatrical forms, leaving no room for love or other individual sentiments.

In Floating Weeds, the story is entirely fictional, authored by Ozu himself and his faithful scriptwriter Kogo Noda. The plot revolves around a modest travelling-theatre company that stations for a time in a small coastal town to perform. The troupe's leading actor Komajurō (Ganjirō Nakamura) has chosen this sleepy location with the secret intention of visiting his former common-law wife, Oyoshi (Haruko Sugimura), and their son, Kiyoshi (Hiroshi Kawaguchi), who takes him for his uncle. However, Komajurō's current lover and the troupe's main actress, Sumiko (Machiko Kyō), soon discovers his secret and arranges for the young actress Kayō (Ayako Wakao) to seduce an unsuspecting Kiyoshi, unleashing Komajurō's fury. With their spectacle failing to attract sufficient audience, the troupe goes bankrupt and disbands, but Komajurō and Sumiko eventually reconcile and hit the road together again.

Ozu's films were often some kind of remake of his own previous works, whether with similar or different titles. However, the choice for this particular remake is peculiar, given the general absence of geidomono pieces 
in the director's filmography. In 1934, it was just natural that a filmmaker would be pushed towards an apolitical genre such as this, with Japan's increasing militarisation and censorship. But as late as 1959, when the country had already surrendered entirely to the spell of American liberal habits and Ozu himself was finally succumbing to the attraction of colour technology, the choice of this old-fashioned genre suggests a particular interest. As stated earlier, Floating Weeds is an exceptional piece in Ozu's oeuvre for many reasons, not least the numerous scenes of violence the likes of which are not to be seen in any of his other films. Physical contact of any kind is conspicuously absent in his oeuvre, except in rare and highly melodramatic climaxes, for example, in the famous scene in Tōkyō Story (Tōkyō Monogatari, 1953), when the poor widow Noriko gives some pocket money to her mother-in-law and, in the process, holds her hand for a moment. It could have been that the different production company, crew, cast and genre gave Ozu the opportunity to offer, through the portrayal of male violence, some kind of implicit (and belated) apology, in the name of his fellow professionals as well as his own, to the appalling treatment devoted to actors in the studio system at the time. The depiction of the troupe's leader, Komajurō, could indeed suggest something along these lines. Despite his endearing attachment to his past lover and son, his leadership over his troupe is enforced through choleric physical and verbal abuse when they act against his will. Even more shocking is the fact that the assaulted characters, Sumiko and Kayō, are played by two of the greatest female celebrities in Japan, respectively Machiko Kyō and Ayako Wakao. Komajurō reacts with equal violence towards his own son, Kiyoshi, who eventually hits back and puts an end to the abuse, sealing the patriarch's demise.

Komajurō's first outburst is unleashed when he discovers that Kayō has been having romantic encounters with Kiyoshi. He calls her to the centre of the theatre where they had previously performed, questions her, slaps her face and when she hesitates to tell the full story, he twists her arm until, under duress, she confesses that she had been paid by Sumiko to seduce the young man. The scene was already present in A Story of Floating Weeds, but here it is enhanced with the addition of torture to extract the final confession. Komajurō subsequently summons Sumiko to his presence on the same spot in the theatre and repeatedly beats her for plotting the seduction game. Taking place in an empty theatre, these physical assaults in a way replace the actors' theatrical performances whose full view is denied to the spectator, except on two highly significant occasions, featuring precisely these female stars as explained below. Instead, it is the inner workings of the system - of both theatre and film - which are revealed with the power 
of bodily pain and emotional stress on the part of the characters, i.e. with heightened realistic enactment.

By deeming these scenes 'realistic', I am certainly not suggesting that anyone was actually hurt in their delivery. However, the mere reiteration of violence within a style that otherwise continues to be as restrained and economical as usual in Ozu indicates the pointed intention to instil in the spectator a sense of physical pain and moral offence. Combined with the rigours of acting imposed by $\mathrm{Ozu}$, as demonstrated by the example of Nakamura and Kyō exposed to the rain until they fell ill, quoted above, the enactment of violence in Floating Weeds must have been a visceral experience for the actors themselves. After spanking and torturing her, Komajurō continues to attack Kayō relentlessly, kicking her in the back, when he finds her sitting on the tatami in their lodgings, and slapping her in the face again when she emerges in Oyoshi's home with Kiyoshi, who now declares his intention to marry her. Komajurō then turns to Kiyoshi, when he tries to protect Kayō, and slaps him in the face three times. Kiyoshi then violently pushes Komajurō, now revealed to be his father, to the floor, declaring that he does not need a father and expelling him from the house. Finally, Komajurō accepts his mistake, apologises to Kayō, asks her future mother-in-law Oyoshi to treat her well, and leaves the place for good.

Going back to what happens on the theatrical side of the story, Komajurō's troupe specialises in a lower, popular form of kabuki called taishū engeki (Russell 2011: 29), which at the time of the film was already outmoded, as observed, within the film, by Kiyoshi to Komajurō when they go fishing together. However, this popular theatre form gives Ozu the opportunity to contravene kabuki's treasured tradition of the onnagata (male actors in female roles), as well as Japanese cinema's female star system itself, by showing, at the first of the only two short theatrical performances in the film, Machiko Kyō, in her role as actress Sumiko, changing her usual femme-fatale persona for that of a male character, namely the legendary social bandit Chuji Kunisada. Interestingly, the episode focuses on Kunisada already past his prime, as he bids farewell to his fellows at Mount Akagi in a melancholy monologue that prefigures the falling apart of the theatre troupe itself at the end of the film (Figure 5.1). More importantly, Sumiko's power to attract the camera to her transvestite performance of a male warrior that metaphorically mocks the declining Komajurō (whose own performance is never shown), as well as Kayō's victory in taking Komajurō's son away from his family, suggests an upcoming gender power reversal both in Japanese society and in the performing arts. Theatre here is the conduit through which the actress ascends to a commanding position, replacing 


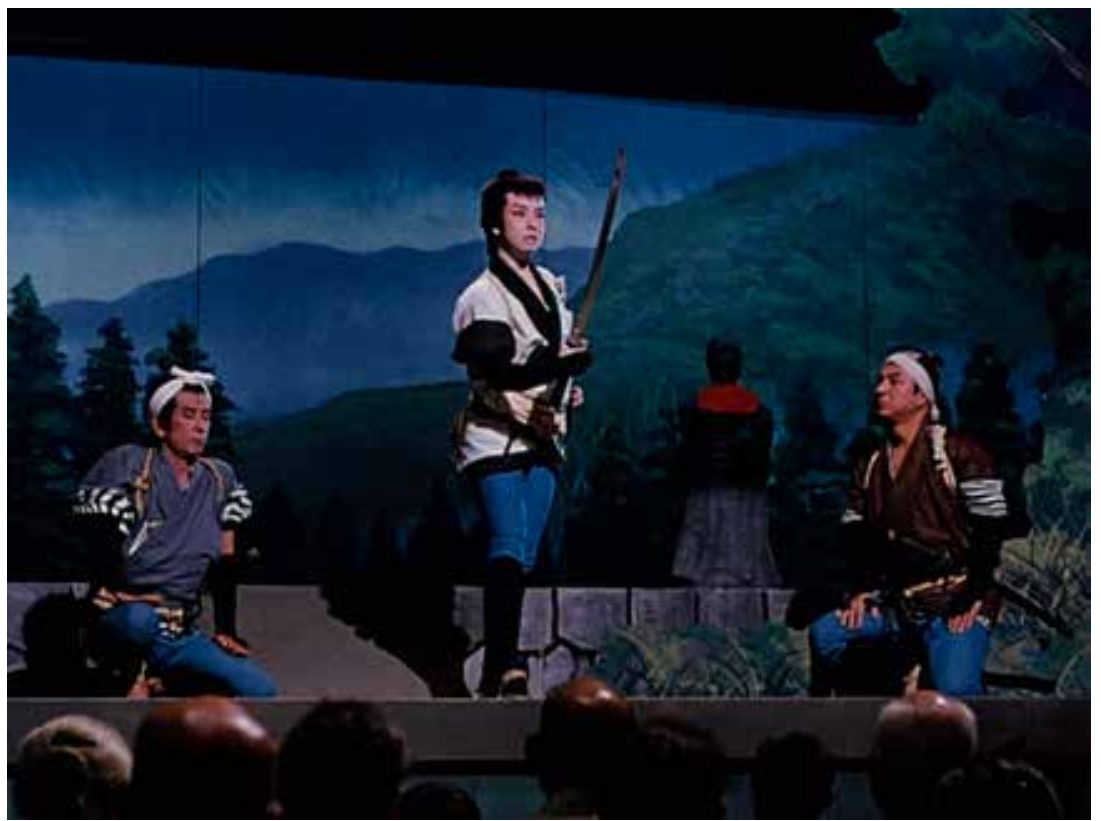

Figure 5.1 Floating Weeds: Ozu contravenes kabuki's treasured tradition of male actors in female roles, as well as Japanese cinema's female star system, by showing Machiko Kyō changing her femme-fatale persona for that of a male character.

her male counterpart and ridding herself of her own feminine celebrity persona. Knowing how self-referential the film is, the parallel between Komajurō and the film director himself is tempting. His actions, too, are all the more realistic for stemming from a mise en scène entirely aware of its artifice and for this reason all the more effective in the criticism they level against the hierarchical system within Japan's theatrical and cinematic traditions.

As in Floating Weeds, in The Story of the Last Chrysanthemums the criticism of the ruthless hierarchy at the heart of kabuki is a structuring element. Physical violence is however not portrayed in the latter, at least not on the part of the tyrannical master, Kikugorō Onoe V, who limits himself to verbally insulting his incompetent stepson and disinheriting him when he asks for permission to marry a servant. However, the innocent and good intentioned Otoku is the subject of physical violence in one, extremely poignant, scene, when she reluctantly refuses to let her unemployed and disgruntled lover Kikunosuke spend the couple's last savings on drinking. He slaps her, but immediately falls into bottomless regret. Like in Floating Weeds, here too mistreatment of women is physically presented to the spectator and portrayed as socially ingrained. 
Feminism in Mizoguchi has been constantly highlighted as one of his main auteurist traits, but also criticised for double standards when it came to directing his own actresses (see, for example, Bock 1990: $33 \mathrm{ff}$ ). This could be exemplified with the case of actress Rieko Kitami, originally cast for the role of Otoku in the film, on recommendation from Shōchiku. As Yoda (1997: 75-76) retells:

She had a sweet and melancholic beauty that suited her character, but she was too accustomed to discontinuous shooting to act in long takes, and Mizoguchi would give no specific instructions to her performance.

After many failed rehearsals, Mizoguchi exploded:

'You are not worthy of an actress. We are not shooting a cape-and-sword film! You are playing with Shōtarō Hanayagi, the greatest shinpa actor!' (Yoda 1997: 76)

So despite the actress's best efforts, and her name having already been publicised as the lead in the film, she was finally dropped and replaced by Kakuko Mori, a shingeki (new theatre) actress and Hanayagi's disciple (Kirihara 1992: 139). Though acknowledging Mori's excellent performance in the film, Yoda (76) still regrets the brutal dismissal of 'poor Mis K.'

Yet, Otoku's portrayal is essentially feminist, as one of film history's most famous long takes in The Story of the Last Chrysanthemums demonstrates. Let us first examine the actions leading to this memorable scene. As mentioned above, the spectator is left puzzled about Kikunosuke's acting skills, as his performance seems excellent in his first on-stage appearance, but is torn to pieces by his stepfather, the great master Kikugorō V. Kikunosuke himself is equally uncertain about his talent, as he is surrounded by a network of secrecy and pretence conveyed, in the film, through the prolific use of props, including platforms, fences, sliding doors and screens. One or more of these props are always placed between Kikunosuke and those who are secretly slighting his acting, in a way that closely resembles the workings of the odogu (props) in kabuki. The interesting effect of odogu is that it interferes not only with space construction but also with time. As Scott (1999: 153-154) explains, 'Kidō [a particular arrangement of odogu] allows the audience to watch the actions of different people and even the workings of their minds simultaneously. It overcomes time and dimension and enables the onlooker to see through walls'. The scene and long take in question illustrate the effect of odogu 


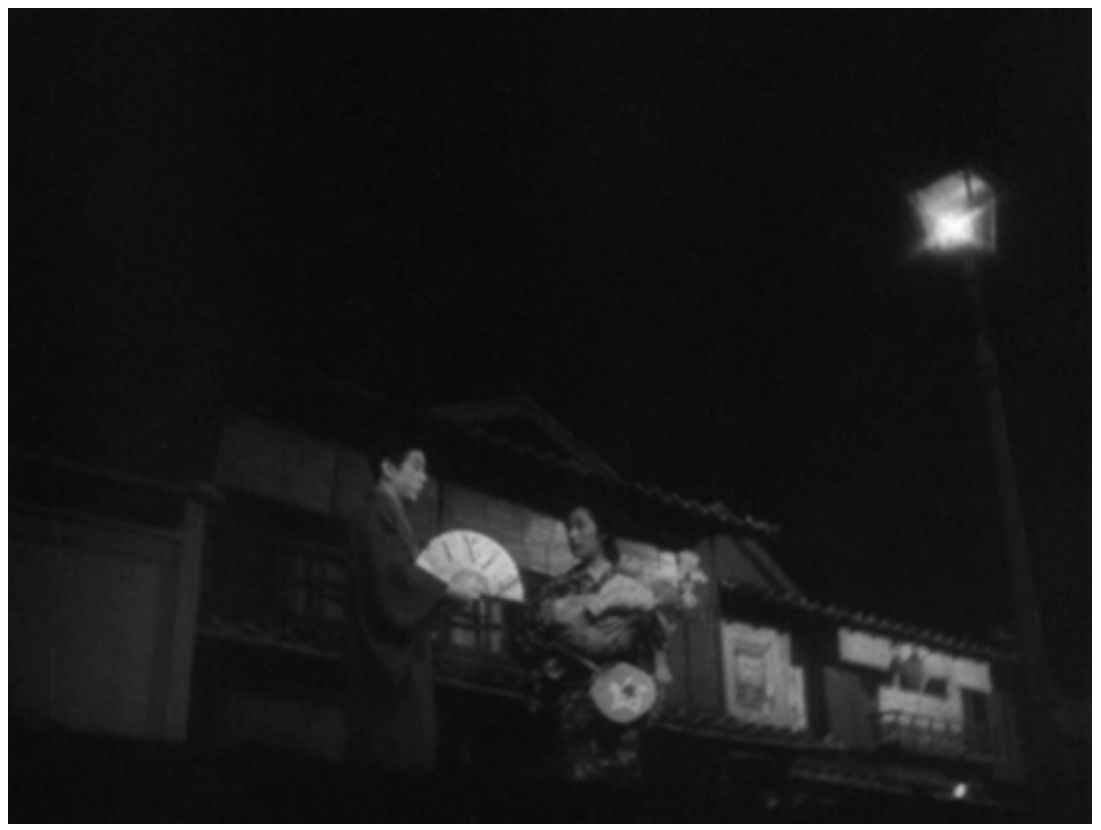

Figure 5.2 The Story of the Last Chrysanthemums: rarely has the fair division of power as the basis for genuine love been so elegantly and powerfully displayed as in this scene, where kabuki explains the camera position below the pavement.

and other theatrical devices combined with the specific properties of the film medium.

After sensing the disguised mockery behind his back on the part of his theatre colleagues and adulating geishas, Kikunosuke returns home in the small hours to find Otoku, the wet nurse of his little stepbrother, in the street trying to bring the baby back to sleep. A long take of five minutes starts by focusing on Otoku on the pavement as Kikunosuke appears and promptly dismisses his rickshaw to walk along with her the rest of the way. As they walk, Otoku tells Kikunosuke for the first time with all honesty that his acting is inadequate, her daringness making room for a slow kind of ballet in which the two characters swap places ahead of each other as they move forward, Kikunosuke occasionally lowering his head in painful realisation of the truth about his skills, and Otoku bowing politely but unrepentantly. Rarely has the fair division of power as the basis for genuine love been so elegantly and powerfully displayed as in this scene, where the lack of cuts allows the female and male actors to alternately lead the camera forward in a smooth tracking shot. During their walk, a series of unlikely events take place, such as the passing of a peddler selling wind chimes, one of which Kikunosuke buys to distract the baby. As Otoku has just remarked on it 
being two in the morning, one wonders how a peddler could be passing by, and he is not the only unlikely creature around: shouts and clapping noises, apparently stemming from other street vendors, are heard, and another street seller rushes past the couple with his trolley, amidst occasional women of the night. This unusual nocturnal crowd serves as information to the viewer of the general demographics in the area at all times, but one which can only be conveyed through disregard to chronology and spatial coherence within the shot.

Thinking along the lines of kabuki, however, clarifies this condensation as analogous to the time and space compression effected by the use of odogu. In particular, kabuki explains the camera position below the pavement, which fails to identify with any plausible point of view of an observer within the scene, but would make perfect sense as the point of view of a kabuki play spectator, sitting below the stage (Figure 5.2). Estrangement is thus elicited at every level to bring home to the film viewer the real specificities of both the film and the theatre mediums, as they produce clash and creative crisis, including the possibility of power reversal within both. At the same time, with its temporal continuum, the long take testifies to the reality of acting whilst documenting the exceptional skills of all involved, in a truly Bazinian tour de force.

\section{Theatrical Passages to Reality}

As a result of his romance with Otoku, which is forbidden due to the class and hierarchical gulf between them, Kikunosuke is expelled from his stepfather's house. He leaves for Ōsaka and leads a life of utter poverty as a lowly actor, alongside a consumptive Otoku. The drama we see evolve is however constitutive part of Kikunosuke's honing of his art, one that the film at once glorifies and condemns. Towards the end of the film, Kikunosuke, having become an accomplished actor, makes a triumphal return to the kabuki scene, in a performance at the Suehiroza, alongside his relatives and protectors Shikan Nakamura and Fukusuke Nakamura. The film then gives us a long kabuki scene, showing him in the famous female role of Sumizome through a series of long and middle-range shots, allowing the viewer scant access to the actor's facial features and actual performance, thanks to the profuse use of odogu props, including screens, barred banisters and other obstacles. In fact, in this most edited section of the film, there seems to be a frantic competition for vantage points to observe the actor's performance on the part of Kikunosuke's family members and helpers from the backstage 
and, more crucially, of Otoku, who at a certain point is crouching in a corner of the backstage but entirely visible behind her performing lover.

Despite this hide-and-seek play with the camera, the sense of a real kabuki theatre is imparted in quasi-documentary long shots of the packed auditorium. Once justified, kabuki's artificial acting becomes cinema, but only by also becoming uncinematic. At the same time, cinema's ability to produce scale reversal and the close-up, the main pillar of the star system, is rejected, denying the actor the privilege of individual fame, whilst placing theatre within its social context, that is, its audience, without which it cannot exist.

In fact, the reality of the audience is one that kabuki, or any theatre, cannot escape from, and the fact that only through the look of others can theatre come into being is stressed in Floating Weeds, as much as in The Story of the Last Chrysanthemums. In the Ozu film, theatre acquires reality insofar as actors become the secret spectators of their audiences, thus reversing the standard voyeuristic position, whilst also exposing cinema's scopic regime. Having become suspicious of Komajurō, Sumiko asks her actor colleagues to help her identify his former lover Oyoshi in the audience. Given that the male actors also have their darlings sitting among the spectators, they all conspire in a collective spying on the audience from the backstage through the cracks of the curtain, turning the theatre audience into spectacle and making the film spectators aware of their own voyeurism, a role now usurped by the objects of their gaze (Figure 5.3). In addition, whilst we are given abundant insight into the actors' preparation for the stage, with an insistent focus on the meticulous and protracted process of make-up application, there is precious little in terms of their actual acting, least of all from Komajurō, whose acting is only once hinted at through the off-screen sound of his recitation. This is, however, entirely in tune with the story of 'a man in denial', in Keiko McDonald's (2006: 97) fitting words, whose make up cannot disguise his age and impending demise (Figure 5.4).

Remakes are self-reflexive by definition, but Floating Weeds is so imbued with medium awareness, that it seems to be purposely following Brecht's (1964) precepts of alienation effects. Needless to say, Ozu was not the least worried about Brecht, but simply exercising his own kind of 'classical modernism', as defined by Catherine Russell (2011: xiii), including a number of 'uncinematic' (Adorno 1981-1982: 201) devices, starting with the rejection of cinema's key property of movement. Both the camera and the objects placed before it remain mostly static in the famous Ozu-style framing of parallel characters conversing in frozen attitudes, in shot-reverse-shot montage. This is compounded by disruptive devices which are constantly at work in 


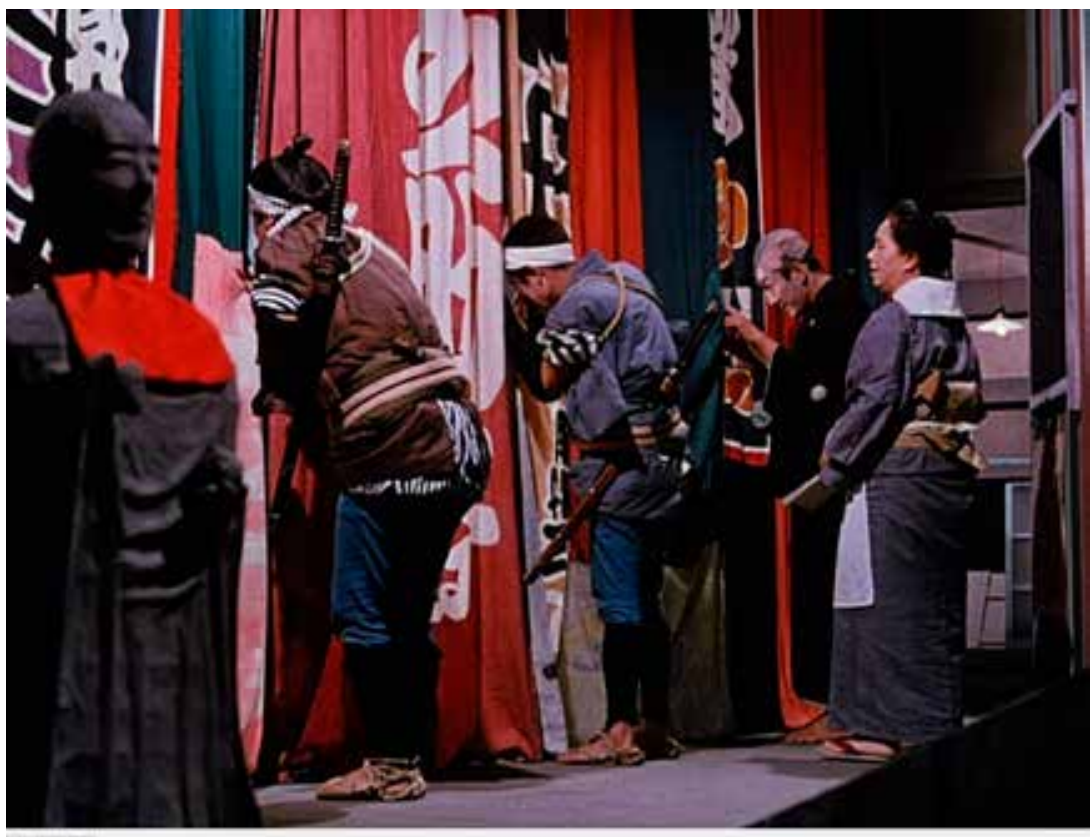

Figure 5.3 Floating Weeds: collective spying on the audience from the backstage through the cracks of the curtain turns the theatre audience into spectacle.

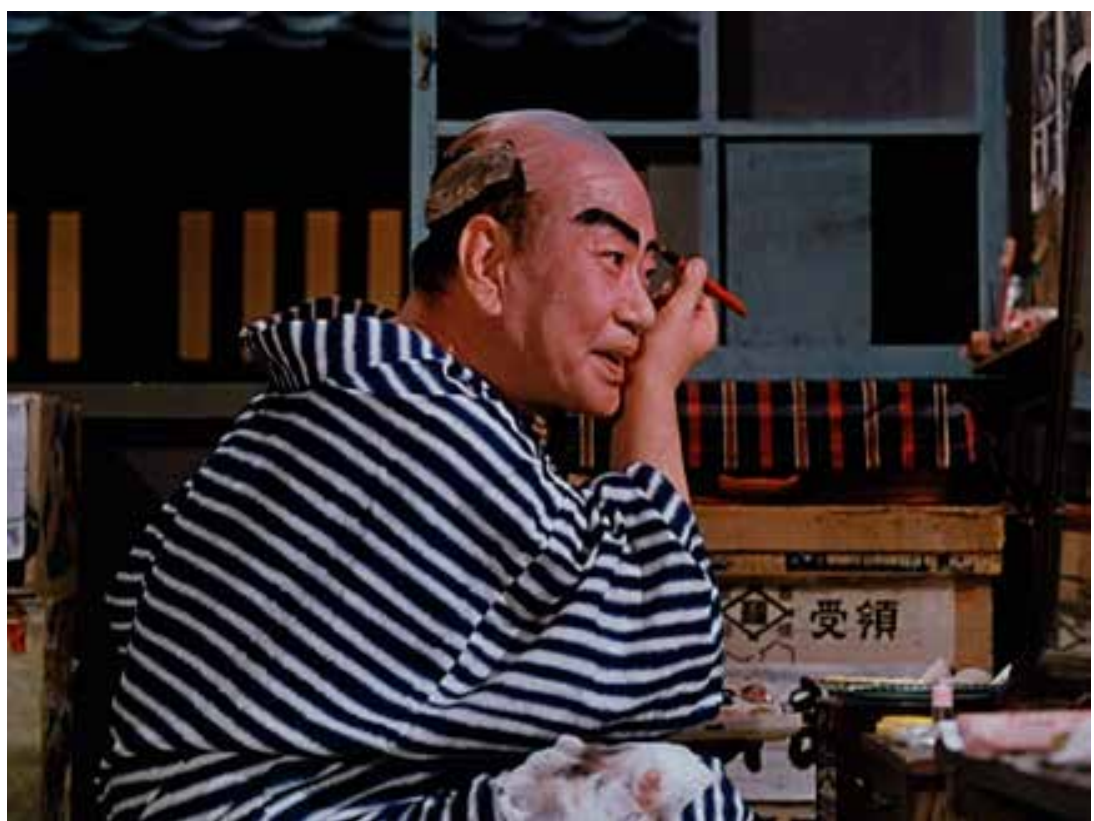

Figure 5.4 Floating Weeds gives abundant insight into the actors' preparation for the stage, but precious little in terms of their actual acting. 
order to bring any action back to a standstill, including actors with a wooden performance, such as the aforementioned Hiroshi Kawaguchi, in the role of Kiyoshi. Whatever sense of movement is conveyed is to do with theatrical performances, which, as in a musical, disrupt the narrative thread to draw the viewer's attention to the artificiality of the story and the reality of the medium. Colour, a new adventure for Ozu, is exaggerated to the point of becoming an object in its own right, with garish reds and blues that call attention to their pictorial extravagance and unnaturalness.

These artificial procedures also inform the structure of Ozu's famous transitional 'curtain shots' or 'pillow shots', abundantly used in the film. All-too often I have read that these are randomly chosen images aimed at producing ellipses of time and space. For Deleuze (1997: 13ff), as noted above, they are pure optical and sound images. Such assessments, however, overlook their crucial narrative role, which often includes self-commentary and reflexivity. Suffice it to look at the staging of the second theatrical scene in Floating Weeds, a song-and-dance piece by the younger actress, Kayō, played by the dazzling Ayako Wakao, accompanied by a child apprentice. The series of transitional shots, or curtain shots, that precede the scene are carefully chosen to radically inflect the narrative, as they show empty spaces and then the makeshift lighting of the venue, indicating the general poverty of the theatre and the calamitous low attendance at the show (Figure 5.5). These shots are entirely in tune with Brecht's recommendations for his own epic theatre that lighting and other theatre equipment should remain visible to the audiences, thus causing a double self-reflexive effect: for the audience within and outside the film. The song-and-dance act then presented is all about breaking the fourth wall and poking fun at the performance itself, with the child actor, expected to perfectly mime the moves of the main dancer, constantly interrupting his performance to collect little packs of money thrown at them by the audience, then bowing reverentially and calling the spectators' attention to the reality of the actor in the play within the story (Figure 5.6).

In conclusion, theatre serves both the Mizoguchi and the Ozu films to break down the system at the base of the mediums of theatre and film into their constitutive parts, provide evidence of their reality, and propose a fairer arrangement of them. As a result, realism becomes closely associated with self-reflexivity, not in autobiographical terms as Satō and Bock would have had it, but as regards the ruthless hierarchy of kabuki and related theatrical forms, which compare to the film directors' demands on the cast themselves and is presented to the viewer through a level of physical violence, most notably in Floating Weeds, which finds no parallel in their work. 


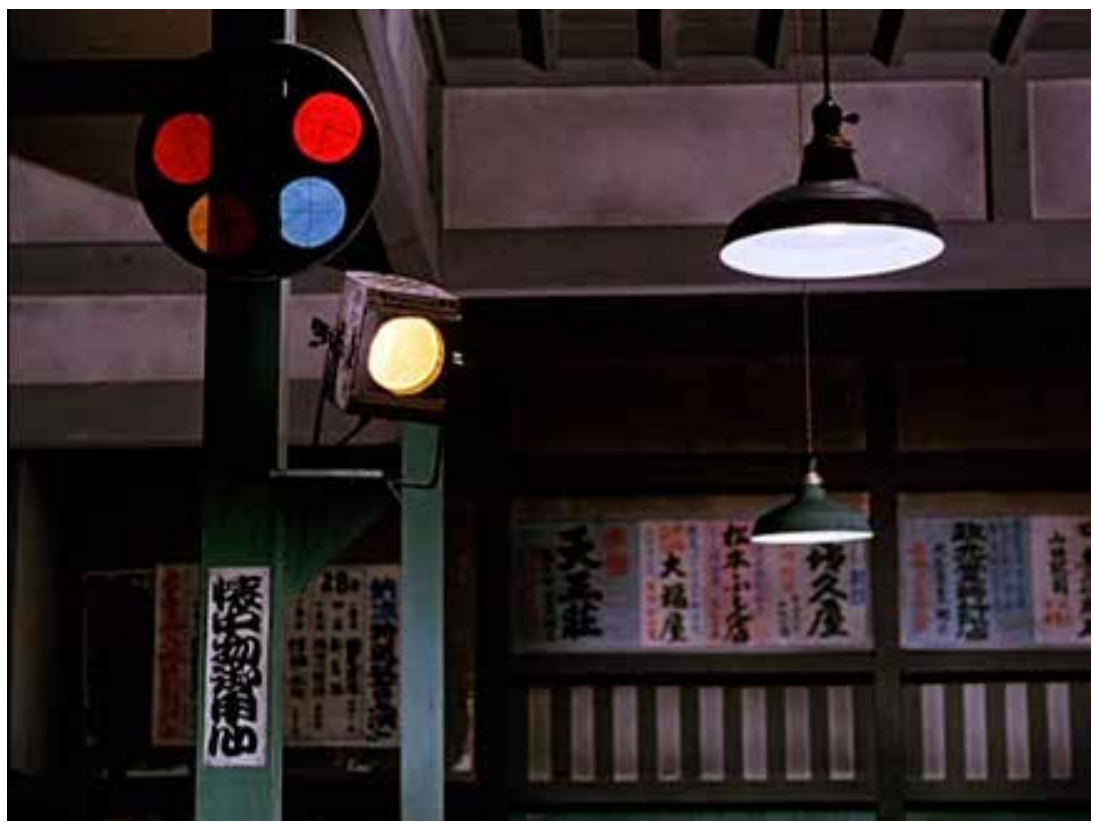

Figure 5.5 Floating Weeds: the makeshift lighting of the venue indicates the general poverty of the theatre.

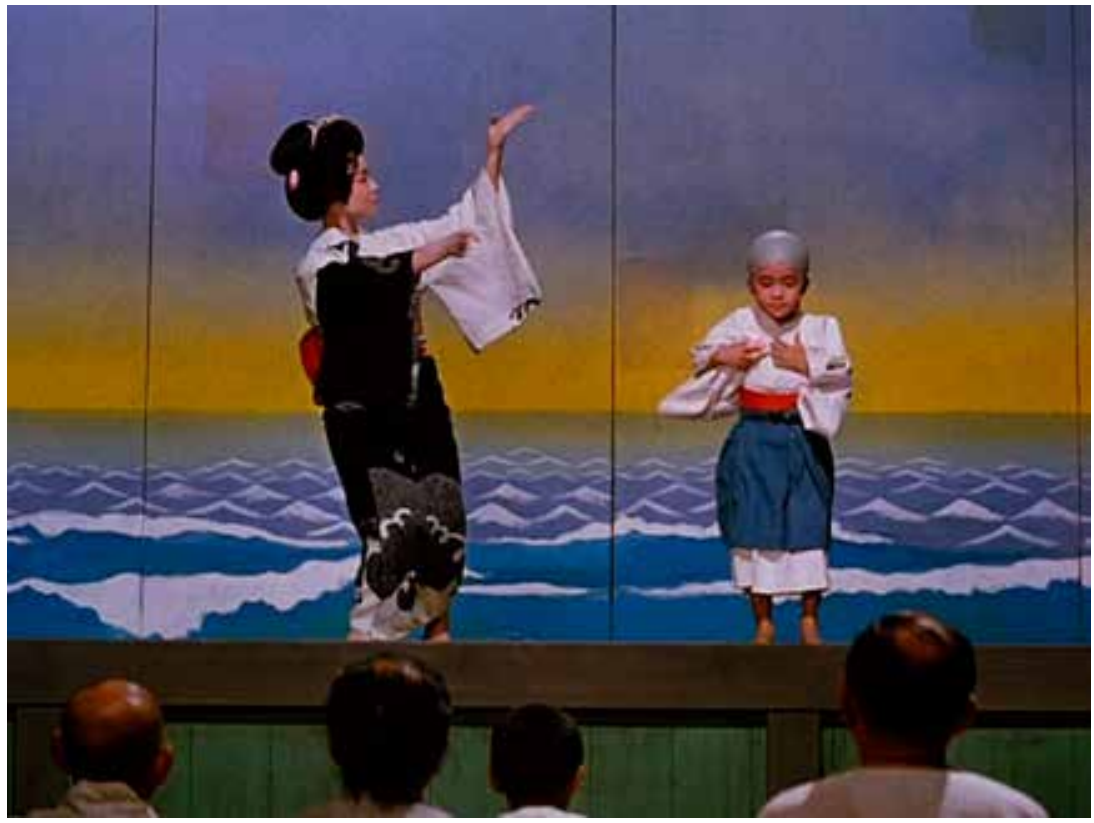

Figure 5.6 Floating Weeds: the song-and-dance act is all about breaking the fourth wall and poking fun at the performance itself, with the child actor interrupting his performance to collect little packs of money thrown by the audience. 
Revelatory realism can also be gleaned from these films' distinctive focus on what happens behind the theatre scene, with extended time devoted to the actors being dressed and made up, and to the description of the internal mechanisms of the stage and props. This is the moment where Burch's 'decentred' camerawork, Godard's 'objects that present themselves without the interference from the mind' and Deleuze's 'images of time' become both presentational and representational passages leading to the physical reality of another art within the virtual medium of film. Thus, the theatre spectacles, on the rare occasions they are presented to the spectator, become infused with the reality of life, not just that of the characters on stage, but also of the actual film actors and their real world.

\section{Bibliograpy}

Adorno, Theodor W.(1981-1982), 'Transparencies on Film', in New German Critique, n. 24/25, Autumn-Winter, pp. 199-205.

Andrew, Dudley (2016), 'The Story of the Last Chrysanthemum: A Cineaste's Performance', On Film/Essays, Criterion Collection, 13 September.

Bazin, André (1967), 'The Evolution of the Language of Cinema', in: What Is Cinema? Vol. 1, essays selected and translated by Hugh Gray. Berkeley/Los Angeles/ London: University of California Press, pp. 23-40.

(1985), 'André Bazin: on Kurosawa's Living (from 'Petit journal du cinéma, Cahiers du Cinéma 69, March 1957)', in: Jim Hillier (ed.), Cahiers du Cinéma: The 1950s - Neo-Realism, Hollywood, New Wave. Cambridge, Massachusetts: Harvard University Press, pp. 261-263. (2005), 'Umberto D: A Great Work', in: What Is Cinema? Vol. 2. Berkeley/ Los Angeles/London: University of California Press, pp. 79-82.

- (2009), 'For an Impure Cinema: In Defence of Adaptation', in: What Is Cinema?, translated by Timothy Barnard. Montreal: caboose, pp. 107-138. (2018), 'La leçon de style du cinéma japonais', in: Écrits complets II, Édition établie par Hervé Joubert-Laurencin. Paris: Éditions Macula, pp. 166o-1662 - (2018), 'Leçon japonaise', in: Écrits complets II, Édition établie par Hervé Joubert-Laurencin. Paris: Éditions Macula, pp. 1667-1668.

Bock, Audie (1990),Japanese Film Directors. Tōkyō/New York: Kodansha.

Bordwell, David (2004), Ozu and the Poetics of Cinema. Ann Arbor, MI: MPublishing, University of Michigan Library, available on https:/quod.lib. umich.edu/c/cjs/og20054.0001.001/1:5.9.2/--ozu-and-the-poetics-of-cinema-david-bordwell?view=toc (accessed 17 April 2020). 
Brecht, Bertolt (1964), Brecht on Theatre: The Development of an Aesthetic, edited and translated by John Willett. London: Methuen.

Burch, Noël (1979), To the Distant Observer: Form and Meaning in the Japanese Cinema. Berkeley/Los Angeles: University of California Press.

Davis, Darrell William (1996), Picturing Japaneseness: Monumental Style, National Identity, Japanese Film. New York: Columbia University Press.

Deleuze, Gilles (1997), Cinema 2: Time-Image. New York/London: Continuum.

Douchet, Jean (1997), 'Préface: Mizoguchi: La réflexion du désir', in: Yoshikata Yoda, Souvenirs de Kenji Mizoguchi. Paris: Cahiers du Cinéma, pp. 4-15.

Godard, Jean-Luc (1986), Godard on Godard, translated and edited by Jean Narboni and Tom Milne. New York: Da Capo.

Harman, Graham (2005), Guerrilla Metaphysics: Phenomenology and the Carpentry of Things. Chicago and La Salle, Illinois: Open Court.

Kirihara, Donald (1992), Patterns of Time: Mizoguchi and the 193os. Madison, Wisconsin: University of Wisconsin Press.

Kishi, Matsuo (1980), 'Larte di Mizoguchi: Domanda sciocche e risposte sagge', interview with Kenji Mizoguchi, in: Adriano Aprà, Enrico Magrelli and Patrizia Pistagnesi (eds.), Il cinema de Kenji Mizoguchi. Venice: La Biennale di Venezia/ ERI-Edizione RAI, pp. 141-143.

Le Fanu, Mark (2005), Mizoguchi and Japan. London: BFI.

McDonald, Keiko I. (2006), Reading a Japanese Film. Honolulu: University of Hawai'i Press.

Metz, Christian (1982), The Imaginary Signifier: Psychoanalysis and the Cinema, translated by Celia Britton, Annwyl Williams, Ben Brewster and Alfred Guzzetti. Bloomington/Indianapolis: Indiana University Press.

Phillips, Alastair (2003), 'Pictures of the Past in the Present: Modernity, Femininity and Stardom in the Postwar Films of Ozu Yasujirō'. Screen, 44.2: pp. 154-166.

Richie, Donald (1974), Ozu. Berkeley/Los Angeles/London: University of California Press.

(2004), 'Stories of Floating Weeds', article in the brochure accompanying the DVD set of A Story of Floating Weeds and Floating Weeds, The Criterion Collection.

Rivette, Jacques (1985), 'Mizoguchi Viewed from Here ('Mizoguchi vu d'ici', Cahiers du Cinéma 81, March 1958)', in: Jim Hillier (ed.), Cahiers du Cinéma: The 1950 s - Neo-Realism, Hollywood, New Wave. Cambridge, Massachusetts: Harvard University Press, pp. 264-265.

Russell, Catherine (2011), Classical Japanese Cinema Revisited. New York/London: Continuum.

Satō, Tadao (1987), Currents in Japanese Cinema. Tōkyō/New York: Kodansha. 
(2008), Kenji Mizoguchi and the Art ofJapanese Cinema, edited by Aruna Vasudev \& Latika Padgaonkar, translated by Brij Tankha. Oxford/New York: Berg. Scott, A. C. (1999), The Kabuki Theatre of Japan. Mineola, New York: Dover Publications.

Takinami, Yuki (2018), 'Modernity, Shōshimin Films, and the Proletarian-Film Movement: Ozu in Dialogue with Vertov', in: Jinhee Choi (ed.), Reorienting Ozu: A Master and his Influence. Oxford: Oxford University Press, pp. 133-154. Visconti, Luchino (1978), 'Anthropomorphic Cinema', in: David Overbey (ed.), Springtime in Italy: A Reader on Neo-Realism. London: Talisman Books, pp. 83-86. Yoda, Yoshikata (1997), Souvenirs de Kenji Mizoguchi. Paris: Cahiers du Cinéma. 